I N S T I T U T O

DE

M E D I C I N A

T R O P I C A L

DE

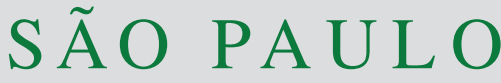

JOURNAL OF THE SÃO PAULO INSTITUTE OF TROPICAL MEDICINE

${ }^{1}$ Hospital São José de Doenças Infecciosas, Fortaleza, Ceará, Brazil

2Universidade de Fortaleza, Faculdade de Medicina, Fortaleza, Ceará, Brazil

${ }^{3}$ Universidade Federal do Ceará, Faculdade de Medicina, Departamento de Saúde Comunitária, Fortaleza, Ceará, Brazil

${ }^{4}$ Universidade Federal do Ceará, Faculdade de Medicina, Departamento de Patologia e Medicina Legal, Fortaleza, Ceará, Brazil

Correspondence to: Matheus Alves de Lima Mota

Universidade de Fortaleza, Faculdade de Medicina, Av. Washington Soares, 1321, Bairro Edson Queiroz, CEP 60811-905, Fortaleza, CE, Brazil

Tel: +5585987757240

E-mail: matheusalm@unifor.br

Received: 26 February 2019

Accepted: 27 August 2019
http://doi.org/10.1590/S1678-9946201961058

\section{An autochthonous case of paracoccidioidomycosis in a new area of Ceara State, Northeastern Brazil}

\author{
Matheus Alves de Lima Mota ${ }^{(1,2}$, Lisandra Serra Damasceno ${ }^{(1,3}$, Silviane \\ Praciano Bandeira ${ }^{\circledR}$, Terezinha do Menino Jesus Silva Leitão ${ }^{(1,3}$
}

\section{ABSTRACT}

The largest endemic areas of paracoccidioidomycosis (PCM) in Brazil comprise the humid agricultural regions of the Southeast, South, and, recently, the Midwest and North regions. The Ceara State, located in the Brazilian Northeast region, presents semi-arid climate in most of its territory, characterized by high temperatures, scarce vegetation and low humidity. The objective of the present study was to describe a new autochthonous case of paracoccidioidomycosis from a distinct area of Ceara and review the characteristics of PCM occurrence in Northeastern Brazil. The patient was a 65-year-old male farmer who denied traveling outside the Ceara State or living in other locations. He was born and lived in the rural area known as Camara, bordering the municipalities of Itapaje and Itapipoca. Camara is one of the highest areas (around $720 \mathrm{~m}$ of altitude) of the Uruburetama mountains that exhibits tropical forests and is located in Northern Ceara, distant $139 \mathrm{~km}$ from the capital, Fortaleza. The patient sought for care, complaining of an oral lesion that appeared over the past three years. The hard palate lesion biopsy revealed multinucleated cells with cytoplasmic inclusions, compatible with PCM. After culture, P. brasiliensis was identified by polymerase chain reaction. Serological testing for PCM was reagent. The patient was treated with itraconazole for approximately 17 months, persisting free of symptoms after 15 months of follow-up. Regarding this new autochthonous case in the Ceara State, PCM should be considered in the differential diagnosis of patients with suggestive clinical manifestations, proceeding from the mountainous areas of Ceara.

KEYWORDS: Fungal diseases. Paracoccidioidomycosis. Ceara. Northeastern Brazil. P. brasiliensis

\section{INTRODUCTION}

Paracoccidioidomycosis (PCM) is an endemic systemic mycosis that is highly prevalent in South America. It is caused by the dimorphic fungi Paracoccidioides spp., and is distributed in at least 5 species: Paracoccidioides brasiliensis (former S1 phylogenetic group), Paracoccidioides americana (former PS2 phylogenetic group), Paracoccidioides restrepiensis (former PS3 phylogenetic group), Paracoccidioides venezuelensis (former PS4 phylogenetic group) and Paracoccidioides lutzii (former $P b 01$-like phylogenetic group). The species $P$. lutzii was identified in restricted endemic areas such as the Brazilian Midwest and North regions ${ }^{1}$.

In Brazil, the largest endemic area includes the Southeast, Midwest and South regions. However, in the 1990s, along with the growth of new agricultural areas, the disease spread to the Eastern border of the Amazon River and, subsequently, to the Western Amazon region, with an incidence of 9.4 cases per 100,000 inhabitants ${ }^{2,3}$. 
Due to geographic characteristics, the Brazilian Northeast region, which, in its majority exhibits semi-arid climate, has shown low endemicity².

A previous study reported only two autochthonous cases from Palmacia in Ceara State ${ }^{4}$. The objective of the present study was to describe a new autochthonous case from a distinct area of Ceara State and review the characteristics of PCM occurrence in Northeastern Brazil.

\section{CASE REPORT}

The patient was a 65 -year-old male farmer that worked primarily on corn and bean crops but also raised a few dairy cows. He was born and lived in Camara, a rural area of the Uruburetama mountains, and denied traveling outside Ceara State or living in other locations, nor did he come in contact with armadillos.

The patient sought for care on September 8, 2016 at the outpatient clinic of Systemic Mycoses of the Sao Jose Hospital of Infectious Diseases, in Fortaleza, Ceara State, complaining of an oral inflammation that had been upsetting him during the past three years. Fever or respiratory symptoms were not reported. The infiltrative oral lesion was located on the palate (Figure 1). In addition, an ulcerative lesion was found on the skin and right nasal mucosa (Figure 2). Hypophonetic cardiac sounds and reduced vesicular murmurs in both lungs were also found. The abdominal examination was normal, and cervical lymph node enlargement was not observed. The patient reported cigarette consumption of 40 packs/year for 40 years but had stopped smoking that past year. After undergoing a chest X-ray, nodules with predominantly

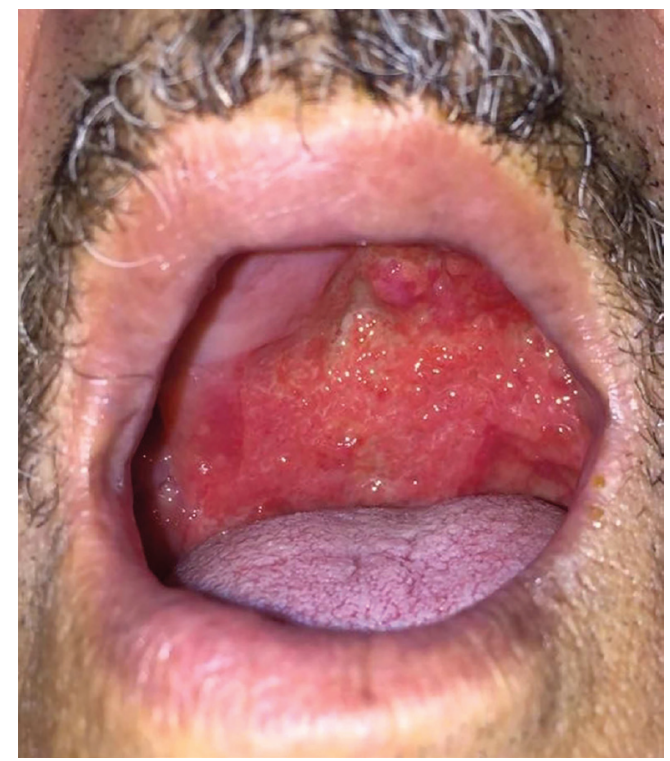

Figure 1 - Infiltrative oral lesion, painful and smelly, similar to moriform stomatitis, with an irregular hyperemic surface located on the palate.

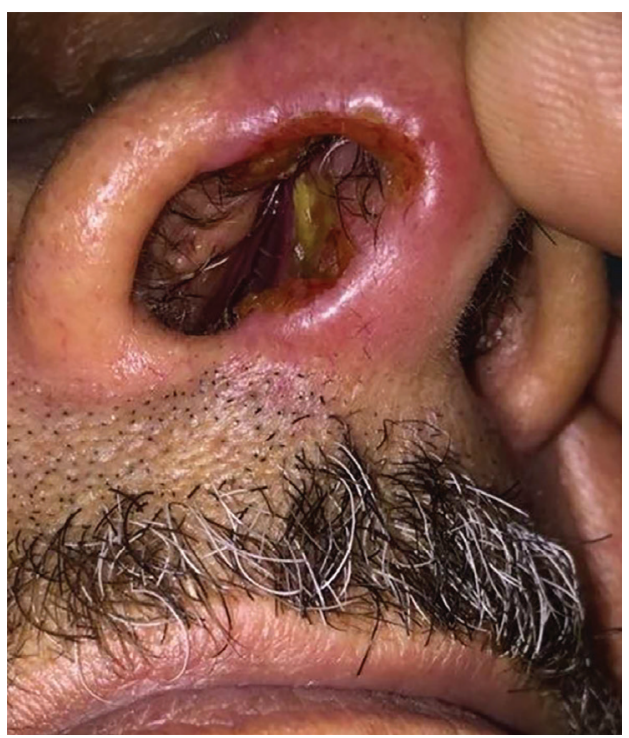

Figure 2 - Ulcerative lesion in the right nasal mucosa and skin.

central distribution were observed affecting both lungs, some showing signs of cavitation and bilateral perihilar reticular infiltrate (Figure 3).

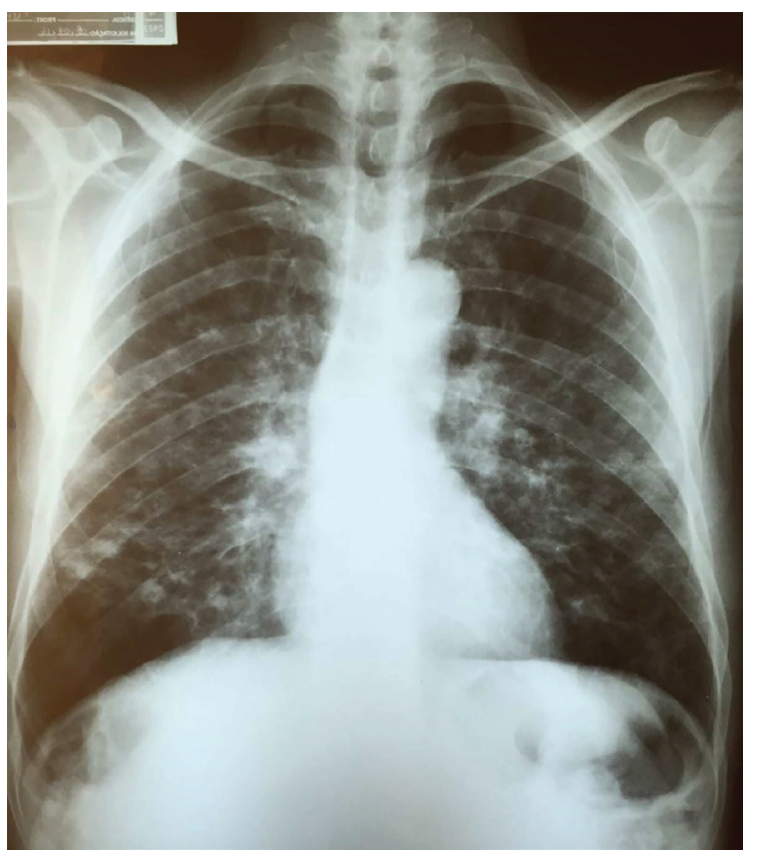

Figure 3 - Chest x-ray showing nodules with predominantly central distribution affecting both lungs, some with signs of cavitation and bilateral perihilar reticular infiltrate.

A previous biopsy of the hard palate lesion revealed a squamous pattern of mucosal fragments presenting granulation tissue associated with chronic lymphohistiocytic infiltrates and multinucleated cells, with cytoplasmic inclusions compatible with a fungal infection, evidenced by PAS and Grocott stains, suggestive of Paracoccidioides spp. yeast forms. Computed tomography (CT) scanning of the face 
revealed a maxillo-ethmoidal sinusopathy, left-deviated bone septum, palatine bulging to the right and an irregularity of the cortical bone of the hard palate on the left side. An imprint of the palatal lesion showed a moderate presence of intra- and extracellular yeast structures with considerably variable sizes (small and oval, medium, large and rounded) by Giemsa staining; Leishmania was not found in the analyzed material.

A new biopsy was performed for microbiological examination and treatment with itraconazole ( $200 \mathrm{mg}$ daily) was initiated at the same day the patient was first seen at Sao Jose Hospital. P. brasiliensis was identified by the polymerase chain reaction (PCR) after fungi growth in culture. For species identification, DNA extraction of yeast cells was performed, based on a previous protocol ${ }^{5}$ with minor modifications, using the DNeasy Plant Mini Kit $\left(\right.$ Qiagen $^{\mathrm{TM}}$, USA). The obtained product was subjected to PCR using panfungal primers ITS1 (5'-TCCGTAGGTGAACCTG CGG-3') and ITS4 (5' -TCCTCCGCTTATTGATATGC-3'). The final $25 \mu \mathrm{L}$ of PCR mix was composed of $2.95 \mu \mathrm{L}$ of ultrapure water, $5.0 \mu \mathrm{L}$ of buffer (Promega, Madison, Wisconsin, USA), $5.0 \mu \mathrm{L}$ of $\mathrm{MgCl}_{2}$ (Promega, Madison, Wisconsin, USA), $5.0 \mu \mathrm{L}$ of dNTP (Promega, Madison, Wisconsin, USA), $2.5 \mu \mathrm{L}$ of each primer (Invitrogen, Thermo Scientific, Waltham, Massachusetts, USA), $0.05 \mu \mathrm{L}$ of Go Hot Start Taq polymerase (Promega, Madison, Wisconsin, USA), and 2.0 $\mu \mathrm{L}$ of DNA template. PCR conditions were: initial denaturation at $95^{\circ} \mathrm{C}$ for $5 \mathrm{~min}$, followed by 30 cycles of $95^{\circ} \mathrm{C}$ for $20 \mathrm{~s}$, annealing at $56^{\circ} \mathrm{C}$ for $15 \mathrm{~s}$, and extension at $72{ }^{\circ} \mathrm{C}$ for $65 \mathrm{~s}$, and a final extension step at $72{ }^{\circ} \mathrm{C}$ for $5 \mathrm{~min}$. The presence of PCR products ( $639 \mathrm{bp}$ ) was verified in $1 \%$ agarose gel electrophoresis. Then, amplicons were sequenced and compared with the P. brasiliensis CBS 372.73 strain (GenBank accession MH860706.1) using the Basic Local Alignment Search Tool (Nucleotide Blast ${ }^{\mathrm{TM}}$ ), resulting in the identification of P. brasiliensis with $98.8 \%$ of similarity.

Double radial immunodiffusion for PCM was positive. The patient was treated with itraconazole for 17 months and evolved with lesion improvement. A white scar over his hard palate caused a retraction in the tonsil topography, but there was no clinical disturbance. The individual had a normal chest X-ray at the end of treatment and had also undergone a new CT scan of the face, which showed a sinusopathy and left-deviated bone septum, but did not evidence the previous bone alterations in the palatal region. He was followed-up until June 6, 2019, persisting free of symptoms.

\section{DISCUSSION}

The geographical distribution of Paracoccidioides spp. is predominantly limited to certain regions of North, Central and South America, characterized by high humid climates and mild temperatures. However, the present study reports an autochthonous case of PCM in a new mountainous area of the Ceara State, a territory that majority lays in the semi-arid region, characterized by high temperatures, scarce vegetation and low humidity, and mean annual rainfalls of $800 \mathrm{~mm}$ per year.

The Camara region (residence of the patient) is located on the borders of the Itapaje and Itapipoca municipalities, in the center of the Uruburetama mountains (Figure 4), Northwestern Ceara State, at -3.63333 ( $3^{\circ} 37^{\prime} 60^{\prime \prime}$ South) latitude and -39.6333 (39 $37^{\prime} 60^{\prime \prime}$ West) longitude. The area of Camara is situated at around $720 \mathrm{~m}$ of altitude and its vegetation is also composed of rainforest. The Uruburetama mountains present significant rainfall indexes varying from 900-1,300 mm, between January and June, and among the observed agricultural activities are banana cultivation and corn and bean crops ${ }^{6}$.

The previous two autochthonous cases were reported in residents of Palmacia (Figure 4), located in the mountains of Baturite, $74 \mathrm{~km}$ West of the capital of Ceara ${ }^{4}$. Palmacia is a predominantly rural city, located at $4^{\circ} 09^{\prime} 01^{\prime \prime}$ South latitude and 38 50' 47" West longitude, at an altitude of $425.11 \mathrm{~m}$. It presents tropical hot-humid climate, with average annual rainfall of $1,386.6 \mathrm{~mm}$, mean annual temperatures between $24^{\circ} \mathrm{C}$ and $26^{\circ} \mathrm{C}^{7}$, and its economy is based primarily on agriculture, namely banana production ${ }^{4,7}$.

Approximately $80 \%$ of the PCM cases reported worldwide were from Brazil, mainly in the Southeast, Midwest and South regions ${ }^{2}$. A second endemic area is located along the Eastern border of the Amazon region ${ }^{8}$, and a third includes the Western Amazon region ${ }^{3}$. Alterations in the epidemiology of PCM have been observed in Brazil, due to factors such as: a) the migration of agriculture and livestock activities to unexplored territories; $b$ ) change to more protective manners, such as mechanical plantation in older endemic areas c) manual family subsistence farming in the Northeast, exposing farm workers to inhalation of fungal spores from the soil. Other implicated factors include increased population density, climate changes, deforestation and soil movement, factors that have caused an increase in PCM cases in endemic areas, mainly of acute/subacute forms ${ }^{2,9}$.

The prevalence of PCM found in the Northeastern region by paracoccidioidin intradermal testing was of $24.2 \%$ in Piaui, $32.1 \%$ in Ceara, $11.2 \%$ to $20.4 \%$ in Rio Grande do Norte, $19.5 \%$ to $57.4 \%$ in Paraiba, $11.2 \%$ in Alagoas and $5.6 \%$ to $21.7 \%$ in Bahia ${ }^{10}$. High prevalences have been observed in endemic areas, including Southeastern Brazil $(39 \%)$ and Colombia $(45 \%)^{2}$.

In Pereiro city, located in a mountainous area distant $342 \mathrm{~km}$ from Fortaleza, the prevalence of 


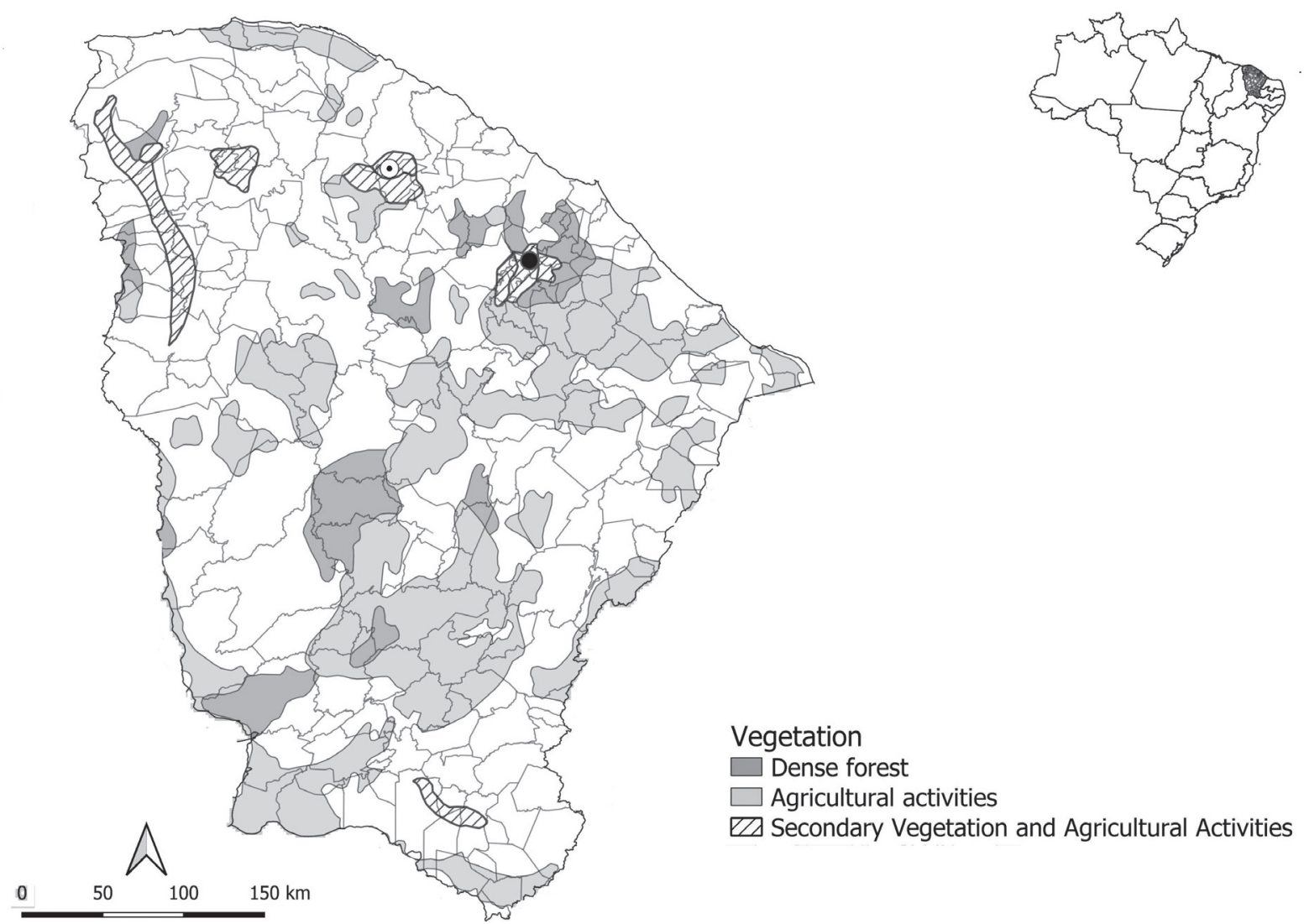

Figure 4 - Areas with autochthonous cases of Paracoccidioidomycosis in the Ceara State, Northeast of Brazil. The black dot shows the location of Palmacia city in Baturite mountain and the white halo with black dot locates the Uruburetama mountain, where the new case was described.

Paracoccidioides spp. infection was $32.1 \%{ }^{11}$. Double immunodiffusion and paracoccidioidin antigen skin testing were also performed in Palmacia, the area in which the first autochthonous case in Ceara was reported ${ }^{12}$. A prevalence of $18.9 \%$ was observed and only one serology for $P$. brasiliensis was positive in the index case. Variations in the results of surveys involving intradermal testing can be due to the antigen and dilution differences used in the studies, aside from cross-reactions between histoplasmin and paracoccidioidin test ${ }^{10}$. In an attempt to reduce these possible biases, the intradermal test using a $43-\mathrm{kDa}$ glycoprotein (specific for $P$. brasiliensis) demonstrated $45.8 \%$ of positivity in Midwestern Brazil ${ }^{13}$.

Between 1998 and 2006, 6,732 hospitalizations occurred due to PCM in Brazil ${ }^{14}$. Admissions were recorded in $27 \%$ of the 5,560 Brazilian municipalities, although they took place in all 26 States of the country. In the Northeast region, a total of 687 admissions for PCM were registered. Maranhao (52.2\%), Piaui (19.8\%), Bahia (14\%) and Ceara (8.3\%) were the States with more hospitalizations due to PCM in this area ${ }^{14}$. Teresina, the capital of Piaui State, ranks tenth among the Brazilian cities with the highest number of admissions ${ }^{14}$. In spite of its location in the semiarid Brazilian Northeast, there are growing areas of agribusiness in Southern Piaui. Furthermore, the city receives patients from several neighboring States.

In studies conducted in Maranhao (Brazilian Northeast) ${ }^{8}$, Espirito Santo ${ }^{15}$, Rio de Janeiro ${ }^{1}$ and Sao Paulo ${ }^{16}$ (Southeastern Brazil), the chronic form was more frequently found in adult men and rural workers. The male/female ratio varies according to the geographic region, from 3:1 to 10:1 in the Brazilian Southeast and Midwest, respectively. Moreover, no racial predisposition was observed ${ }^{16}$. The most affected organs were oropharyngeal mucosa, upper airway tract, lungs, lymph nodes and skin. In the case reported herein, similar clinical forms affecting the nasal and palate regions were observed.

According to the Brazilian guidelines for the clinical management of $\mathrm{PCM}^{17}$, the chronic form is more common in men aged between 30 and 60 years old. The duration of symptoms is variable and can be greater than one year due to the lack of access to medical assistance or delay in the fungus diagnosis ${ }^{17}$. Smoking, high alcohol intake and malnutrition are factors that contribute to the progression of the disease $\mathrm{e}^{18,19}$. 
Late diagnosis of this mycosis can lead to sequelae in different organs due to chronic inflammatory processes, fibrosis and deformities. Involvement of the upper respiratory tract may lead to complications such as dysphonia, vocal cord lesions and laryngeal obstructions ${ }^{19}$. In the present study, the patient presented a deformity in the hard palate, although no speech or swallowing impairment was reported.

The main differential diagnosis of PCM should be mucocutaneous leishmaniasis, endemic in Ceara. Nevertheless, painful oral lesions and hoarseness are mainly associated with PCM, whereas nasal obstruction is more related to mucocutaneous leishmaniasis ${ }^{20}$. The present case report demonstrates both, oral and nasal involvement, uncommon in PCM. However, it was widely assessed by histopathology, culture, serology, and molecular testing, confirming the diagnosis of PCM.

The gold standard for PCM diagnosis is based on the fungal identification by direct visualization or culture of clinical samples or tissues. Double immunodiffusion can also be used in association with clinical features. However, the variation in antigen production, unavailability of commercial kits and the lack of validation of $P$. lutzii and cross-reactions with other fungal infections have limited the use of this test. Nonetheless, sensitivity ranged between 69-100\% and specificity between $80-100 \%$. Even though molecular tests, such as PCR, are expensive and only available at referral centers for mycoses sensitivity and specificity were high and enabled the species identification ${ }^{19}$.

Although PCM is uncommon and frequently neglected in Northeastern Brazil, it should be considered mainly in male adults and farmers from mountainous areas, with pulmonary or chronic mucosal lesions. It is noteworthy that human migration, expansion of agricultural borders, climate and environmental changes, and new agricultural and social practices have been causing an impact on the occurrence of Paracoccidioides spp. infection and $\mathrm{PCM}^{2}$, a fact that may help explaining the identification of new areas with the presence of the fungus.

\section{CONCLUSION}

Paracoccidioides spp. infection should be considered in populations from the mountainous areas of Ceara. More studies are needed in the region to better elucidate the risk factors related to the presence of the fungus in the environment.

\section{ACKNOWLEDGMENTS}

Our thanks to the staff of the Medical Archive and Statistics Service, the Laboratory of Microbiology and the Study Center of the Sao Jose Hospital of Infectious Diseases. We also thank the Laboratory of Mycology of the Federal University of Ceara for their support in diagnosis.

\section{AUTHORS' CONTRIBUTIONS}

Matheus Alves de Lima Mota: data collection and compilation, literature review, article writing; Lisandra Serra Damasceno: data and text review, article writing; Silviane Praciano Bandeira: laboratory support, culture diagnosis and PCR, article writing; Terezinha do Menino Jesus Silva Leitão: data and text review, article writing.

\section{FUNDING}

No funding sources.

\section{REFERENCES}

1. Macedo PM, Teixeira MM, Barker BM, Zancopé-Oliveira RM, Almeida-Paes R, Francesconi do Valle AC. Clinical features and genetic background of the sympatric species Paracoccidioides brasiliensis and Paracoccidioides americana. PLoS Negl Trop Dis. 2019;13:e0007309.

2. Martinez R. New trends in paracoccidioidomycosis epidemiology. J Fungi (Basel). 2017;3:1.

3. Vieira GD, Alves TC, Lima SM, Camargo LM, Sousa CM. Paracoccidioidomycosis in a western Brazilian Amazon State: clinical-epidemiologic profile and spatial distribution of the disease. Rev Soc Bras Med Trop. 2014;47:63-8.

4. Façanha MC, Souza AQ, Café VS, Wanke B. Paracoccidioidomycosis: description of two cases autochthonous in Ceará. Braz J Infect Dis. 2010;14:86-8.

5. Irinyi L, Serena C, Garcia-Hermoso D, Arabatzis M, DesnosOllivier M, Vu D, et al. International Society of Human and Animal Mycology (ISHAM)-ITS reference DNA barcoding database: the quality controlled standard tool for routine identification of human and animal pathogenic fungi. Med Mycol. 2015;53:313-37.

6. Lima DL, Cordeiro AM, Bastos FH. Agentes condicionantes e desencadeadores de movimentos gravitacionais de massa na vertente úmida do maciço de Uruburetama, Ceará, Brasil. Rev Bras Geogr Fis 2015;8:1142-57.

7. Instituto de Pesquisa e Estratégia Econômica do Ceará. Perfil municipal 2017: Palmácia. Fortaleza: IPECE; 2018. [cited 2019 Jun 9]. Available from: https://www.ipece.ce.gov.br/ wp-content/uploads/sites/45/2018/09/Palmacia_2017.pdf

8. Matos WB, Dos Santos GM, Silva VE, Rosário Gonçalves EG, Silva AR. Paracoccidioidomycosis in the state of Maranhão, Brazil: geographical and clinical aspects. Rev Soc Bras Med Trop. 2012;45:385-9. 
9. Francesconi do Valle AC, Macedo PM, Almeida-Paes R, Romão AR, Lazéra MS, Wanke B. Paracoccidioidomycosis after highway construction, Rio de Janeiro, Brazil. Emerg Infect Dis. 2017;23:1917-9.

10. Fava SC, Fava Netto C. Epidemiologic surveys of histoplasmin and paracoccidioidin sensitivity in Brazil. Rev Inst Med Trop Sao Paulo. 1998;40:155-64.

11. Diógenes MJ, Gonçalves HM, Mapurunga AC, Alencar KF, Andrade FB, Nogueira-Queiroz JA. Reações à histoplasmina e paracoccidioidina na Serra de Pereiro (estado do Ceará Brasil). Rev Inst Med Trop Sao Paulo. 1990;32:116-20.

12. Façanha MC, Café VS, Wanke B, Souza AQ, Bornay F, Coelho Filho JM. Estudo soroepidemiológico de paracoccidioidomicose em Palmácia - CE. Rev Soc Bras Med Trop. 1991;24 Supl 2:28-9.

13. Marques AP, Oliveira SM, Rezende GR, Melo DA, FernandesFitts SM, Pontes ER, et al. Evaluation of Paracoccidioides brasiliensis infection by gp 43 intradermal test in rural settlements in Central-West Brazil. Mycopathologia. 2013;176:41-7.

14. Coutinho ZF, Wanke B, Travassos C, Oliveira RM, Xavier DR, Coimbra CE. Hospital morbidity due to paracoccidioidomycosis in Brazil (1998-2006). Trop Med Int Health. 2015;20:673-80.
15. Peçanha PM, Ferreira ME, Peçanha MA, Schmidt EB, Araújo ML, Zanotti RL, et al. Paracoccidioidomycosis: Epidemiological and clinical aspects in 546 cases studied in the State of Espírito Santo, Brazil. Am J Trop Med Hyg. 2017;97:836-44.

16. Martinez R. Epidemiology of paracoccidioidomycosis. Rev Inst Med Trop Sao Paulo. 2015;57 Suppl 19:11-20.

17. Shikanai-Yasuda MA, Mendes RP, Colombo AL, Telles FQ, Kono A, Paniago AM, et al. II Consenso Brasileiro em Paracoccidioidomicose: 2017. Epidemiol Serv Saude. 2018;27 Num Esp:e0500001.

18. Santos WA, Silva BM, Passos ED, Zandonade E, Falqueto A. Associação entre tabagismo e paracoccidioidomicose: um estudo de caso-controle no Estado do Espírito Santo, Brasil. Cad Saude Publica. 2003;19:245-53.

19. Griffiths J, Lopes Colombo A, Denning DW. The case for paracoccidioidomycosis to be accepted as a neglected tropical (fungal) disease. PLoS Negl Trop Dis. 2019;13:e0007195.

20. Vicente CR, Falqueto A. Differentiation of mucosal lesions in mucocutaneous leishmaniasis and paracoccidioidomycosis. PLoS One. 2018;13:e0208208. 